\title{
High heterotrophic counts in potable water and antimicrobial resistance among indicator organisms in two peri-urban communities of Karachi, Pakistan
}

\author{
Sadia Shakoor ${ }^{1,2^{*}} \mathbb{1}$, Imran Ahmed ${ }^{1}$, Saima Mukhtiarr ${ }^{1}$, Israr Ahmed ${ }^{1}$, Farzeen Hirani ${ }^{2}$, Shazia Sultana ${ }^{2}$ \\ and Rumina Hasan ${ }^{1}$
}

\begin{abstract}
Objective: Fecal contamination of potable water leads to unsafe water supply. Although many urban areas of large metropolitan cities receive safe water, peri-urban areas are often not monitored by public health authorities and water supply and quality remain unknown. We assessed microbiological quality and rates of antimicrobial resistance in viable indicator bacteria in two peri-urban communities of Karachi, Pakistan. Water samples were collected over 5 months (October 2015 to February 2016) from these peri-urban communities and samples were processed for microbiological quality as per Standing Committee of Analysts, United Kingdom and World Health Organization guidelines and criteria for drinking water.

Results: Both communities received unimproved water. Potable water samples collected from 100 households showed that $96 \%$ of samples were unsafe for consumption. Extended spectrum beta lactamases production was found in $29.2 \%$ of fecal indicator organisms (coliforms). Use of unimproved water sources and unsafe potable water quality in peri-urban Karachi deserve immediate attention and upgrade. The study is instrumental in attracting the attention of authorities to the state of water resources in peri-urban communities in Karachi with a view to influence improvement of services and effects on human health.
\end{abstract}

Keywords: Potable water, Household, Heterotrophic plate count, Peri-urban, Antimicrobial resistance

\section{Introduction}

Safe drinking water is a basic human right [1] and sustainable development goal (SDG) 6 endorses efforts toward provision of safe and affordable drinking water for all by 2030 [2]. Lack of access to safe drinking water negatively impacts human health and results in childhood illness, infectious outbreaks, food security, and livelihood [3]. Deleterious health effects of water shortage are observed in underserved communities, many of which are located around populated megacities. Karachi is a coastal megacity in southern Pakistan with a population of 16 million,

\footnotetext{
*Correspondence: sadia.shakoor@aku.edu

${ }^{1}$ Pathology \& Laboratory Medicine, Aga Khan University, Karachi, Pakistan Full list of author information is available at the end of the article
}

and an annual growth rate of 6\% [4]. Karachi's urban geography is surrounded by a large peri-urban agglomerate. A recent review identified Karachi as one of four highly vulnerable megacities with regard to water supply and urban water security [5].

Peri-urban communities are in transition between urban and rural settings. Supply and quality of natural resources such as water are often inadequate in periurban communities [6] around expanding megacities such as Karachi. Piped water may not always be available and consumers often rely on groundwater sources, draw water from distribution lines through suction pumps, or purchase water from vendors [7]. Since only municipal piped water may be chlorinated, the quality of water reaching peri-urban areas suffers from high levels of 
contamination. For similar reasons, measures to monitor and maintain microbiological standards of water overlook peri-urban areas. Therefore, little is known about water sources, quantity, and quality of potable water in these areas of Karachi.

Data from the Global Enteric Multicenter Study (GEMS) showed a high burden of childhood diarrhea in peri-urban Bin Qasim Town of Karachi, and extremely limited access to improved water sources [8]. Many pathogens in the study with high attributable fractions for childhood diarrhea are water-borne, suggesting that microbiological quality of potable water must be examined. Monitoring of microbiological water quality is a prerequisite for risk benefit analysis to define practical safety limits for drinking water and human health impact. In this non-hypothesis, descriptive study, we have assessed potable water sources and microbiological quality in the peri-urban communities of Bin Qasim town of Karachi. The data provides insight into existing water sources and contamination levels with the ultimate purpose of identifying health risks and highlighting opportunities for improvement of health outcomes of peri-urban communities in Karachi.

\section{Main text \\ Methods \\ Study sites}

Cattle Colony (CC) and Rehri Goth (RG) are peri-urban localities around cattle-farming and fishing communities, respectively, in the Bin Qasim town of Karachi (Fig. 1a). The sites were included in the Global Enteric Multicenter Study as surveillance sites for diarrhea in children and have an established Health and Demographic Surveillance System. The sites receive piped water supply from the Kinjhar lake system (Fig. 1b).

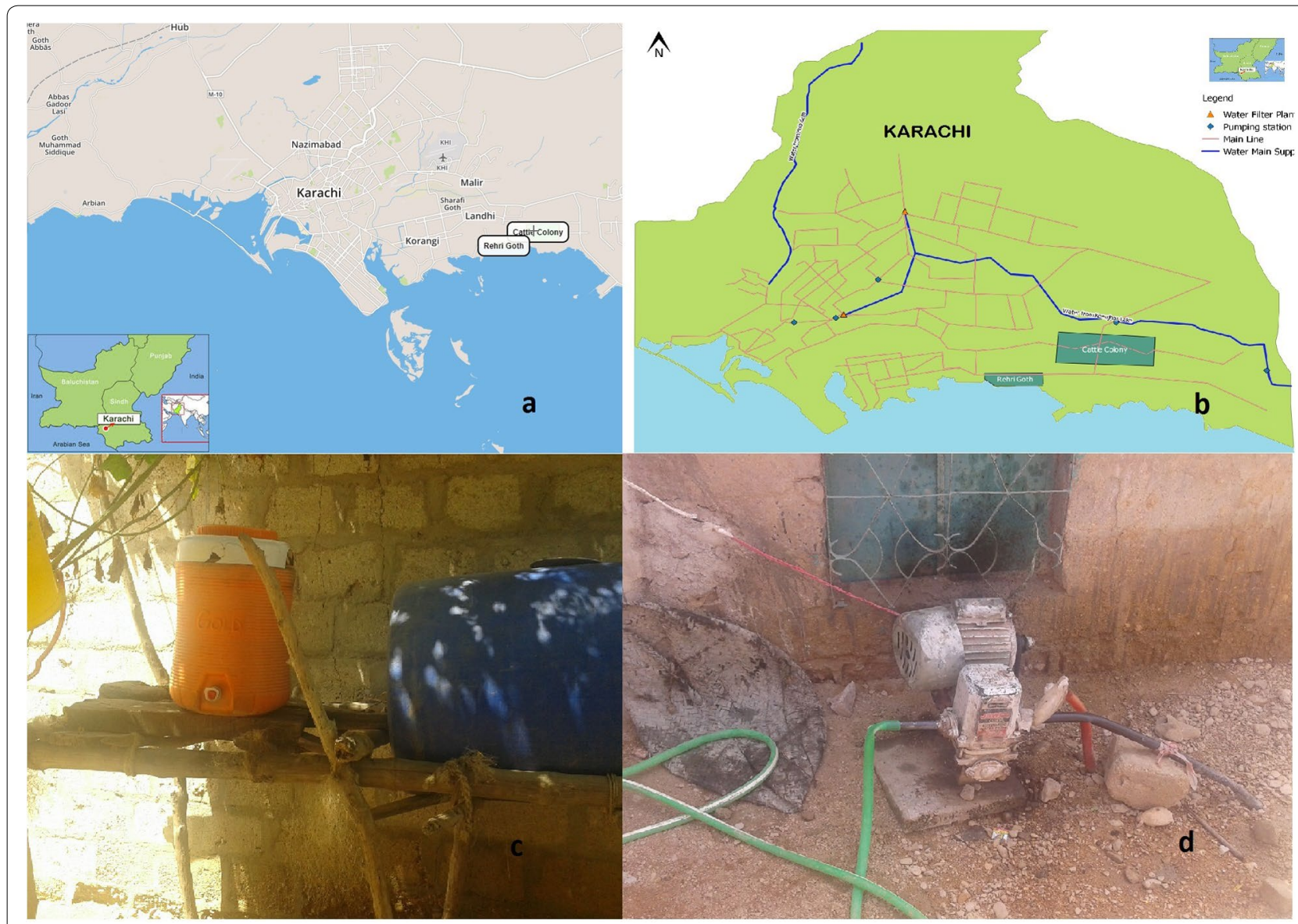

Fig. 1 Study areas in Karachi and water supply and consumption; a Map of Cattle Colony and Rehri Goth in the Bin Qasim Town of Karachi (Insets show location of Karachi within Pakistan and Pakistan in South Asia); b water distribution system in Karachi showing piped water supply to study areas from a natural lake east of Karachi; $\mathbf{c}$ water storage tanks used in some households; and $\mathbf{d}$ pressure booster pumps used by consumers to overcome low pressure and intermittent supply of piped water 


\section{Sampling methods}

Household water $(500 \mathrm{~mL})$ was collected in sterile plastic containers with sodium thiosulfate from 50 households each in CC and RG, from October 2015 to February 2016. Water was collected directly (without prior run-off) from sources of consumption in households (Fig. 1c). Samples were transported at room temperature within $4 \mathrm{~h}$ of collection to the Aga Khan University clinical microbiology laboratory for processing.

\section{Microbiological methods and susceptibility testing}

Water samples were processed within $24 \mathrm{~h}$ of receipt at the laboratory. Turbidity was measured by the turbidity tube method [9] and results were recorded in turbidity units (TUs). For heterotrophic plate counts (HPCs), $1 \mathrm{~mL}$ of water was added to $19 \mathrm{~mL}$ of yeast extract agar (Oxoid) and placed at $37^{\circ} \mathrm{C}$ and results were read at $44 \pm 4 \mathrm{~h}$ as recommended by the Standing Committee of Analysts, United Kingdom (SCA, UK) guidelines [10-12]. HPC counts were read with a colony counter on the $100 \mathrm{~mm}$ petri plate, the count limit for which was 5700 colony forming units $(\mathrm{CFU}) / \mathrm{mL}$. For coliforms and thermotolerant E. coli, $100 \mathrm{~mL}$ of water was filtered through a $47 \mathrm{~mm} 0.45$ Millipore filter (Merck) and the membrane placed onto Membrane lauryl sulfate agar (Conda Laboratories). Two paired volumes were inoculated onto MLSA and placed at $30{ }^{\circ} \mathrm{C}$ for $4 \mathrm{~h}$ followed by incubation for $14 \mathrm{~h}$ at $37^{\circ} \mathrm{C}$ (for presumptive coliform growth) and $44{ }^{\circ} \mathrm{C}$ (for presumptive E. coli growth). Presence of coliforms and $E$. coli was recorded and counts were not performed. For confirmation of coliforms and E. coli, oxidase test and a combination of sulfide, and indole production were used, respectively. For recovery of Salmonella and Shigella, buffered peptone water was set up at $37^{\circ} \mathrm{C}$ for $24 \mathrm{~h}$, followed by Rappaport Vassiliadis broth (Oxoid) enrichment and culture on xylose lysine deoxycholate agar (Oxoid) to recover colored colonies (pink-red-yellow with or without black centers).

Overall microbiological quality was considered acceptable if no coliforms and/or E. coli were recovered from $100 \mathrm{~mL}$ of sample [13]. Since $>500 \mathrm{CFU} / \mathrm{mL}$ of HPC inhibit recovery of coliforms and $E$. coli on lactose containing media, HPC counts exceeding $500 \mathrm{CFU} / \mathrm{mL}$ were also considered unacceptable [14], irrespective of the recovery of coliforms and thermotolerant $E$. coli.

A subset of randomly selected coliforms and $E$. coli were subjected to antimicrobial susceptibility testing. Briefly, identification was confirmed with Activity profile Index (API) $20 \mathrm{E}$ (bioMereiux), and colonies of selected isolates were suspended in sterile normal saline to achieve a turbidity of $0.5 \mathrm{McF}$ arland, and tested as per manufacturer's recommendations on the Gram negative
Vitek (bioMereiux) card. Antibiotics tested included piperacillin, ceftazidime, ciprofloxacin, meropenem, and trimethoprim-sulfamethoxazole. Extended Spectrum Beta Lactamase (ESBL) production was determined by the Vitek Advanced Expert System (AES) through determination of susceptibility against third generation cephalosporins and ceftazidime.

\section{Data entry and analysis}

All data was entered and frequencies and medians were calculated using SPSS v19.0 (IBM). Median HPCs were compared using Mann-Whitney U test.

\section{Results \\ Household characteristics}

Of 100 households included in the study, piped water supply was available in $55 \%(\mathrm{n}=55 ; 38$ in $\mathrm{CC}$ and 17 in RG), water was purchased from contractual tanker hydrant suppliers in $36 \%$ ( $n=36 ; 8$ in CC and 28 in RG), and groundwater was used in $9 \%(n=9 ; 4$ in $C C$ and 5 in RG). Households with piped water supply used pressure boosting pumps to ensure continuous supply of water (Fig. 1d). Neither boiling nor chlorination were used in any of the households; 2 households in $\mathrm{CC}$ filtered piped water. More than half (55\%; $\mathrm{n}=55,40$ in $\mathrm{CC}$ and 15 in RG) used vessels for storage of drinking water; others used these directly from the source.

\section{Turbidity and microbiological acceptability}

Turbidity was $<5$ TUs in $67 \%$ of samples, 10 TU in $7 \%$ of samples, and $>10$ but $<20 \mathrm{TU}$ in 26 samples, with visible particulate matter.

Microbiological quality was unacceptable in 96\% of samples. Heterotrophic Plate Counts (HPCs) and recovery of coliforms and thermotolerant E. coli from samples in CC and RG are shown in Table 1. Very high HPCs inhibited growth of coliforms and E. coli in $4 \%$ of samples, but these were considered unacceptable based on their high HPCs. Salmonella spp. and Shigella spp. were not recovered from any samples. Median HPCs did not significantly differ between piped and purchased water sources $(\mathrm{p}=0.1)$.

\section{Antimicrobial resistance}

Antimicrobial resistance was further evaluated in randomly selected 113 indicator organisms recovered from 100 samples. Resistance rates against common antibiotics are shown in Table 2. Data presented show a higher resistance against cephalosporins, fluoroquinolones, and cotrimoxazole in E. coli than in other coliforms. Carbapenem resistance was not detected. 
Table 1 Proportion of piped water supply source and microbiological acceptability of potable water samples from households in Cattle Colony (CC) and Rehri Goth (RG) peri-urban communities of Karachi, Pakistan

\begin{tabular}{llll}
\hline & CC & RG & Total \\
\hline \% Piped source & $76(n=38)$ & $34(n=17)$ & $55(n=55)$ \\
Median HPC (IQR) & 4004 CFU/mL (1647-5700) & 5700 CFU/mL (2779-5700) & $5700(1781.5-5700)$ \\
\% Microbiologically unacceptable & $92(n=46)$ & $100(n=50)$ & $96(n=96)$ \\
\% Samples with coliforms isolated & $90(n=45)$ & $94(n=47)$ & $92(n=92)$ \\
\% Samples with thermotolerant E. coli isolated & $26(n=13)$ & $44(n=22)$ & $35(n=35)$ \\
& 50 & 50 & 100 \\
\hline
\end{tabular}

Table 2 Resistance to third generation cephalosporins, ciprofloxacin, and trimethoprim sulfamethoxazole among randomly selected organisms cultured from potable water in peri-urban households

\begin{tabular}{|c|c|c|c|c|c|}
\hline \multirow[t]{2}{*}{ Organism } & \multirow[t]{2}{*}{ Number } & \multicolumn{3}{|c|}{$\%$ Resistant (n) } & \multirow[t]{2}{*}{ Total } \\
\hline & & Ceftazidime & Ciprofloxacin & $\begin{array}{l}\text { Trimethoprim/ } \\
\text { sulfamethoxazole }\end{array}$ & \\
\hline E. coli & 37 & $43.2(16)$ & $10.8(4)$ & $29.7(11)$ & 37 \\
\hline Enterobacter spp. & 17 & $5.9(1)$ & 0 & $29.4(5)$ & 17 \\
\hline Klebsiella pneumoniae & 56 & $26.8(15)$ & 0 & $8.9(5)$ & 56 \\
\hline Citrobacter spp. & 3 & $33.3(1)$ & 0 & 0 & 3 \\
\hline Total & 113 & $29.2(33)$ & $3.5(4)$ & $18.6(21)$ & 113 \\
\hline
\end{tabular}

\section{Discussion}

Results from our study show a very high recovery rate of heterotrophic organisms from household potable water in peri-urban Karachi, with a high fecal contamination rate. Governance and infrastructural challenges in periurban areas hinder sustainable water supply and management [6], which in turn lead to unsafe microbiological quality of potable water. Our results reflect these underlying challenges in peri-urban community dwellings of Karachi. Routine monitoring of peri-urban water supply systems is also not carried out, and resulting high levels of microbial counts may lead to adverse human health outcomes. These results therefore indicate that periurban areas are in urgent need of attention with respect to water supply, safety and sustainability.

Our results also show the multiplicity of methods employed to obtain water. Piped water was not uniformly accessible, and where available, had insufficient hydraulic pressure and was interrupted, prompting residents to employ pressure booster pumps (Fig. 1d). Negative pressures in piped systems draw water from contaminated groundwater and even leaky sewage lines [15]. Furthermore, use of water lifting and booster pumps further increase contamination through ingress of air and surge effects.

Previous assessments of water quality in urban Karachi have established high levels of microbial contamination.
The 2014 Multiple Indicator Cluster Survey (MICS) [16] demonstrated that $74.9 \%$ of households were using contaminated water with coliform counts of $>1 \mathrm{CFU} / \mathrm{mL}$. In our study, rates are likely higher due to peri-urban location. Moreover, our interpretation of microbiological quality also included high HPCs as an indicator of inhibited coliform growth [17]. Since the MICS survey and the Pakistan National Quality Standards (NQS) for Drinking Water [18] did not consider HPCs when evaluating water quality, the proportion of unsafe water quality may be underestimated. In our study, we identified 4 samples with high HPCs and no coliform yield, suggesting that such instances are likely to be encountered with a finite frequency. We therefore recommend that NQS should include HPCs and consider high HPC counts (>500 CFU/mL) to indicate water is unsafe for consumption.

High levels of HPCs have also been correlated with seasonal changes, increasing in summer months and during the wet season [19]. We collected water samples in winter months with little or no rain in Karachi, therefore our results are not likely to be high owing to seasonal changes.

While point-of-use disinfection remains a viable option safe potable use, technologies used may not be accessible, affordable, reliable, or even safe [20]. Techniques such as boiling are inherently unsafe due to the risk of burns 
[21], especially in crowded households with large volume needs. Chlorination of water by end users remains a useful strategy, is affordable, but consistent use requires a change in behavior and practices which need long-term investments in community education [22].

Antimicrobial resistance in the environment is an emerging concern. Higher rates of resistance among thermotolerant $E$. coli than in other pathogens, which may have multiple other sources than human and animal guts (such as industrial wastewater, vegetable dead matter, and soil) [23], reflect antibiotic resistance among the human and animal populations as being the main drivers for the observed resistance in water. This suggestion requires further confirmation through culture and molecular studies. Our results also show low prevalence of extended spectrum beta lactamase mechanisms (as indicated by third generation cephalosporin resistance) among indicator coliforms. Since many bacteria may not be recovered on culture, detection of antibiotic resistance genes (ARGs) may be a better indicator of prevalent transferrable resistant genes in water [24]. Although overall trends in quantity of antibiotic resistant bacteria may correlate with ARGs [25], the potential role of drinking water in transmission and acquisition of antibiotic resistance in humans remains unknown.

\section{Conclusions}

Lack of adequate water supply and unsafe water has important implications on citizenship and social engagement [26] of communities. We have highlighted the problem of microbiologically unsafe potable water among peri-urban households in Karachi, which can have harmful physiological and psychological impact on the health of peri-urban dwellers. Urgent operational preventive measures to allow adequate resource allocation, community engagement and educational measures at the household level are necessary to avoid these health risks.

\section{Limitations}

Our study did not focus on variations in rainfall and seasonal effects, dissolved organic matter, and chemical composition of water, all of which impact water quality and may also impact risk to human health. However, our findings remain an important indicator of the need for infrastructural as well as educational reforms to improve water quality to prevent enteric infections.

Both poor water quality and presence of indicators of human fecal contamination strongly suggest presence of diarrheal pathogens which could not be recovered due to use of only conventional methods. In addition, overwhelming numbers of bacteria as indicated by very high HPCs also interfere with pathogen detection and coliform isolation [17].

\begin{abstract}
Abbreviations
API: activity profile index; ARG: antibiotic resistance gene; C: centigrade; CC: Cattle Colony (Karachi peri-urban study area); CFU: colony forming units; GEMS: Global Enteric Multicenter Study; E.coli: Escherichia coli; ESBL: extended spectrum beta lactamase; HPC: heterotrophic plate count; IQR: interquartile range; MICS: Multiple Indicator Cluster Survey; mL: milliliter; NQS: National Quality Standards; RG: Rehri Goth (Karachi peri-urban study area); SCA: Standing Committee of Analysts; SDG: sustainable development goals; spp: species; TU: turbidity unit; UK: United Kingdom; WHO: World Health Organization.
\end{abstract}

\section{Authors' contributions}

SS1, SM, and IA1 analyzed and interpreted the data and compiled the results. IA2 and SM performed laboratory work. FH and SS2 performed and coordinated informed consents, sample collection, transport to the laboratory and feedback to study households. SS1 wrote the manuscript. RH provided guidance during all stages of the study. All authors read and approved the final manuscript.

\section{Author details}

1 Pathology \& Laboratory Medicine, Aga Khan University, Karachi, Pakistan.

2 Pediatrics \& Child Health, Aga Khan University, Karachi, Pakistan.

\section{Acknowledgements}

We are grateful to Faisal Malik, Imran Ahmed Chaudhry, and Benazir Baloch for providing mapping and artwork services.

\section{Competing interests}

The authors declare that have no competing interests.

\section{Availability of data and materials}

The datasets generated and/or analysed during the current study are available from the corresponding author on reasonable request.

\section{Consent for publication}

Not applicable.

\section{Ethics approval and consent to participate}

The study protocol was reviewed and approved by the Ethical Review Committee for the Aga Khan University. Individual written informed consents were obtained from household members of consenting age before water samples were collected.

\section{Funding}

The study was funded by the International Foundation for Science, Sweden.

\section{Publisher's Note}

Springer Nature remains neutral with regard to jurisdictional claims in published maps and institutional affiliations.

Received: 1 March 2018 Accepted: 31 May 2018

Published online: 04 June 2018

\section{References}

1. Langford M. The United Nations concept of water as a human right: a new paradigm for old problems? Int I Water Resour Dev 2005;21(2):273-82.

2. Griggs D, Stafford-Smith M, Gaffney O, Rockström J, Öhman MC Shyamsundar P, Steffen W, Glaser G, Kanie N, Noble I. Policy: sustainable development goals for people and planet. Nature. 2013;495(7441):305.

3. Zhang J. The impact of water quality on health: evidence from the drinking water infrastructure program in rural China. J Health Econ. 2012;31(1):122-34.

4. Government of Pakistan. Pakistan Bureau of Statistics. Province-wise provisional results of census 2017. http://www.pbs.gov.pk/sites/default/ files/PAKISTAN\%20TEHSIL\%2OWISE\%2OFOR\%2OWEB\%20CENSUS_2017. pdf. Accessed 20 May 2018. 
5. Keys PW, Wang-Erlandsson L, Gordon L. Megacity precipitation sheds reveal tele-connected water security challenges. PLOS ONE. 2018;13(3):e0194311.

6. Douglas I. Peri-Urban ecosystems and societies: transitional zones and contrasting values. In: McGregor D, Simon D, Thompson D, editors. The peri-urban interface: approaches to sustainable natural and human resource use. Milton Park: Taylor and Francis; 2006. p. 18-26.

7. Allen A, Dávila JD, Hofmann P. The peri-urban water poor: citizens or consumers? Environ Urban. 2006:18(2):333-51.

8. Kotloff KL, Nataro JP, Blackwelder WC, Nasrin D, Farag TH, Panchalingam $S$, et al. Burden and aetiology of diarrhoeal disease in infants and young children in developing countries (the Global Enteric Multicenter Study, GEMS): a prospective, case-control study. Lancet. 2013;382(9888):209-22.

9. World Health Organization. Fact Sheet 2.33 Turbidity measurement. http://www.who.int/water_sanitation_health/hygiene/emergencies/ fs2_33.pdf. Accessed 16 Feb 2018.

10. The Standing Committee of Analysts. The Microbiology of Drinking Water (2012) — part 7—methods for the enumeration of heterotrophic bacteria. Methods for the examination of waters and associated materials. London: Environment Agency; 2012.

11. The Standing Committee of Analysts. The Microbiology of Drinking Water (2009) — part 4-methods for the isolation and enumeration of coliform bacteria and Escherichia coli (including E. coli O157:H7). Methods for the examination of waters and associated materials. London: Environment Agency; 2009

12. The Standing Committee of Analysts. The microbiology of drinking water (2006) - part 9-methods for the isolation and enumeration of Salmonella and Shigella by selective enrichment, membrane filtration and multiple tube-most probable number techniques. Methods for the examination of waters and associated materials. London: Environment Agency; 2006.

13. WHO (World Health Organization). Guidelines for drinking-water quality. 4th ed. Geneva: WHO; 2011.

14. Reasoner DR. Monitoring heterotrophic bacteria in potable water. In: McFeters GA, editor. Drinking water microbiology_-progress and recent developments. New York: Springer-Verlag; 1990. p. 452-77.

15. WHO, World Health Organization. Safe piped water: managing microbial water quality in piped distribution systems. London: IWA Publishing: 2004.
16. Sindh Bureau of Statistics and UNICEF. 2015. Sindh Multiple Indicator Cluster Survey 2014, Final Report. Karachi, Pakistan: Sindh Bureau of Statistics and UNICEF. http://sindhbos.gov.pk/wp-content/uploa ds/2014/09/01-Sindh-MICS-2014-Final-Report.pdf. Accessed 6 Feb 2018.

17. Heibati M, Stedmon CA, Stenroth K, Rauch S, Toljander J, Säve-Söderbergh M, Murphy KR. Assessment of drinking water quality at the tap using fluorescence spectroscopy. Water Res. 2017;15(125):1.

18. Government of Pakistan. Pakistan Environmental Protection Agency. (Ministry of Environment). National Standards for Drinking Water Quality. (NSDWQ). June, 2008. Ministry of Health, World Health Organization, UNICEF. http://www.environment.gov.pk/act-rules/DWQStd-MAY20 07.pdf. Accessed 16 Feb 2018.

19. Allen MJ, Edberg SC, Reasoner DJ. Heterotrophic plate count bacteria-what is their significance in drinking water? Int J Food Microbiol. 2004;92(3):265-74.

20. Mintz E, Bartram J, Lochery P, Wegelin M. Not just a drop in the bucket: expanding access to point-of-use water treatment systems. Am J Public Health. 2001:91(10):1565-70.

21. Clasen TF, Thao DH, Boisson S, Shipin O. Microbiological effectiveness and cost of boiling to disinfect drinking water in rural Vietnam. Environ Sci Technol. 2008;42(12):4255-60.

22. Oswald WE, Lescano AG, Bern C, Calderon MM, Cabrera L, Gilman RH. Fecal contamination of drinking water within peri-urban households, Lima, Peru. Am J Trop Med Hyg. 2007;77(4):699-704.

23. Kuhn I, Allestam G, Stenstrom GA, Mollby R. Biochemical fingerprinting of water coliform bacteria, a new method for measuring coliform diversity and for comparing different bacterial populations. Appl Environ Microbiol. 1991;57(11):3171-7.

24. Berendonk TU, Manaia CM, Merlin C, Fatta-Kassinos D, Cytryn E, Walsh F, et al. Tackling antibiotic resistance: the environmental framework. Nat Rev Microbiol. 2015;13(5):310.

25. Xi C, Zhang Y, Marrs CF, Ye W, Simon C, Foxman B, Nriagu J. Prevalence of antibiotic resistance in drinking water treatment and distribution systems. Appl Environ Microbiol. 2009;75(17):5714-8.

26. Anand N. Pressure: the politechnics of water supply in Mumbai. Cult Anthropol. 2011;26(4):542-64.
Ready to submit your research? Choose BMC and benefit from:

- fast, convenient online submission

- thorough peer review by experienced researchers in your field

- rapid publication on acceptance

- support for research data, including large and complex data types

- gold Open Access which fosters wider collaboration and increased citations

- maximum visibility for your research: over $100 \mathrm{M}$ website views per year

At $\mathrm{BMC}$, research is always in progress.

Learn more biomedcentral.com/submissions 